\title{
Chemical constituents and technological functional properties of acerola (Malpighia emarginata DC.) waste flour
}

Tamara Rezende MARQUES ${ }^{1 \star}$, Angelita Duarte CORRÊA ${ }^{1}$, Jéssica Boreli dos Reis LINO , Celeste Maria Patto de ABREU1', Anderson Assaid SIMÃO ${ }^{1}$

\begin{abstract}
Acerola is a fruit that can be consumed in the form of juice and pulp. However, during its processing, a large amount of waste is generated (seed and bagasse). Adding value to these by-products is of great interest, since their use can enrich foods with nutrients and fiber. In this study, we performed phytochemical screening, determined the proximate and mineral composition, bioactive compounds and the technological functional properties of acerola seed flour and acerola bagasse flour. Seeds were dried in a ventilated oven at $\pm 45^{\circ} \mathrm{C}$ and the bagasse was lyophilized. Samples were ground, stored in flasks protected from light. Phytochemical screening revealed metabolites of nutritional and pharmacological interest and no potentially toxic substances in the flours. Seed flour and bagasse flour showed high levels ( $100 \mathrm{~g}^{-1}$ of dry matter - DM) of soluble fiber: 4.76 and 8.74; insoluble fiber: 75.76 and 28.58, and phenolic compounds: 4.73 and 10.82, respectively. The flours also showed high absorption of water, oil and emulsion stability, presenting potential for inclusion in meat products and bakery products.
\end{abstract}

Keywords: seed; bagasse; chemical characterization.

\section{Introduction}

Most substances of interest in fruit are generally found in parts often discarded, such as peel, bagasse and seeds. Studies have shown that agro-industrial residues often have high contents of protein, carbohydrate, and polyunsaturated lipids, besides metabolic or physiological elements, which are beneficial to the human body, such as fibers, phenolic compounds, and antioxidant substances (NUNES et al., 2009). Thus, some residues can be used in low-cost food production. Despite numerous benefits, however, these parts are usually discarded in most consumption purposes, which results in a huge amount of waste. Moreover, some residues can also contain toxic or antinutritional substances such as protease inhibitors.

The processing of acerola juice generates residues of approximately $40 \%$ of production volume, consisting mainly of seeds and bagasse (peel and leftover pulp) (LOUSADA JÚNIOR et al., 2006). Considering that these residues are characterized as potential pollutants, creating alternatives for reducing this amount of residues is of great importance. However, in order to properly harness and add value to the material, it is essential to determine its chemical composition based on scientific and technological investigations.

Only a few studies about the chemical components of these residues were found in the literature review. While studying the chemical composition of acerola seed flour, Aguiar et al. (2010) observed contents of: protein (18.70); ether extract (4.33); ash (0.49); total fiber (29.29) and vitamin C (0.08) in $100 \mathrm{~g}^{-1}$ of dry matter (DM). In acerola residues containing seeds and bagasse, Sousa et al. (2011) reported contents of: proteins: $1.98{\mathrm{~g} 100 \mathrm{~g}^{-1}}^{-1}$

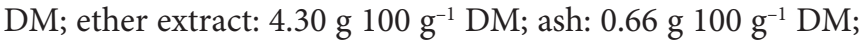

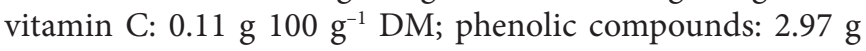

$100 \mathrm{~g}^{-1} \mathrm{DM}$, carotenoids: $1.06 \mathrm{mg} 100 \mathrm{~g}^{-1} \mathrm{DM}$ and anthocyanins: $10.59 \mu \mathrm{g} 100 \mathrm{~g}^{-1} \mathrm{DM}$.

Knowing the technological functional properties of food is essential for food industry, since they are physical and chemical aspects that contribute to achieve features desired by consumers. Thus, potential commercial by-products should be tested for these properties in order to define their intended use (NAVES et al., 2010). No studies on the technological functional properties of acerola were found in either seed flour or bagasse flour.

Therefore, this study aimed to perform the phytochemical screening, determine the proximate and mineral composition, bioactive and/or antinutritional compounds in both acerola seeds flour and acerola bagasse flour, analyzing the technological functional properties of these flours in order to ensure their incorporation into foods.

\section{Materials and methods}

\subsection{Sampling and sample preparation}

Residues (seeds and bagasse) of acerola Malpighia emarginata DC Variety BRS 238 Frutacor from pulp extraction were supplied by a fruit pulp company located in Perdões, State of Minas Gerais, Brazil. Three batches were collected and mixed into a single one to be used in all experiments. Seeds were washed with running water, scrubbed to remove any residual pulp and weighed still wet. The bagasse was frozen at $-18{ }^{\circ} \mathrm{C}$, and then seeds and bagasse were dehydrated as described below. 


\subsection{Dehydrating acerola residues and preparing the flours}

Seeds were placed in ten fine mesh metallic material baskets containing $400 \mathrm{~g}$, and dehydrated at a temperature of $45^{\circ} \mathrm{C}$ in a forced air oven. Readings for loss of seed weight were performed every 24 hours. The baskets were removed from the oven, weighed on a 3 decimal place semi analytical balance and quickly returned to the oven until constant weight. The bagasse was freeze-dried in twelve beakers containing $250 \mathrm{~g}$ portions, and protected from light until constant weight.

After dehydration, seeds and bagasse were ground in a knife mill (TE $631 \mathrm{Tecnal}^{\circ}$ ) for 3 minutes, packaged in hermetically sealed vials and protected from light in a refrigerator. Then, the flours underwent analysis in triplicate.

\subsection{Analyses}

\section{Particle size of flours}

A sieve shaker was used to determine the particle size of both acerola seed flour (ASF) and acerola bagasse flour (ABF). A 30 g-portion of each sample was sieved for 10 minutes, using a set of five round sieves, openings 10, 40, 60, 80 and 100-mesh and a base. The contents retained in each sieve were weighed and expressed in retention percentages.

\section{Phytochemical screening}

Acerola seed flour (ASF) and acerola bagasse flour (ABF) underwent phytochemical screening process. Specific reagents were applied to each chemical group in chemical reactions resulting in change of color or precipitate formation, or both, which is particular for each substance class as tannins, catechins, flavonoids, cardiac glycosides, lactones, carotenoids, steroids, depsides and depsidonas, saponins and alkaloids (MATOS, 1997).

\section{Proximate and mineral composition}

Proximate composition (moisture, ether extract, crude protein $(\mathrm{N} \times 6.25)$, ashes, dietary fiber and nitrogen-free extract) was determined with the method of the Association of Official Analytical Chemists - AOAC (2005).

For quantifying minerals ( $\mathrm{Fe}, \mathrm{Zn}, \mathrm{Mn}, \mathrm{Cu}, \mathrm{Ca}, \mathrm{Mg}, \mathrm{P}$, $\mathrm{K}$ and $\mathrm{S}$ ), ASF and ABF were subjected to nitric perchloric digestion in digester blocks with temperature control. P and S were determined by colorimetry, $\mathrm{K}$ by flame photometry and $\mathrm{Ca}, \mathrm{Mg}, \mathrm{Cu}, \mathrm{Mn}, \mathrm{Zn}$ and Fe by atomic absorption spectroscopy (MALAVOLTA; VITTI; OLIVEIRA, 1997).

\section{Vitamin C}

Vitamin C was determined by the colorimetric method described by Strohecker and Henning (1967). Ascorbic acid was extracted with $0.5 \%$ oxalic acid, in the ratio $1: 30(\mathrm{w} / \mathrm{v})$. After filtration, vitamin $\mathrm{C}$ was dosed in the extract, using ascorbic acid as standard.

\section{Nitrate}

Nitrate was extracted with distilled water at $45^{\circ} \mathrm{C}$, in the ratio $1: 20(\mathrm{w} / \mathrm{v})$. In the dosage, a complex is formed by nitration of salicylic acid under highly acidic conditions, read at $410 \mathrm{~nm}$ in basic solutions ( $\mathrm{pH}$ above 12). Potassium nitrate was used as standard (CATALDO et al., 1975).

\section{Saponin}

Saponin was extracted with $99 \%$ ethanol, in the ratio $1: 10(\mathrm{w} / \mathrm{v})$, under stirring for 1 hour at room temperature. The extract was centrifuged at $10,000 \times \mathrm{g} / 10$ minutes and the supernatant was collected. The level of saponin was determined colorimetrically $(\lambda=430 \mathrm{~nm}$ ) by reaction with anisaldehyde in acidic media, using digitonin as standard (BACCOU; LAMBERT; SAUVAIRE, 1977).

\section{Oxalic acid}

The method of Loures and Jokl (1990) was applied for oxalic acid quantification, in which oxalic acid was extracted with hot $\mathrm{HCl}$, in the ratio $1: 5(\mathrm{w} / \mathrm{v})$ and the precipitate quantified by titration with calcium oxalate potassium permanganate.

\section{Trypsin inhibitors}

Trypsin inhibitors were extracted with $\mathrm{NaOH} 0.1 \mathrm{~mol} \mathrm{~L}^{-1}$ with magnetic stirring in the ratio 1:20 (w/v) (KAKADE et al., 1974). After centrifugation, an aliquot of the supernatant was used in the enzyme assay. Trypsin activity was determined according to the methodology proposed by Erlanger, Kokowsky and Cohen (1961).

\section{Phytate}

Phytate was extracted with $\mathrm{HCl}$ in the ratio 1:20 (w/v) for one hour at room temperature, the $\mathrm{pH}$ adjusted to 6.0 and the sample centrifuged. The extract was eluted through an anion exchange resin to remove the inorganic phosphorus compounds and other interferences. The phytate content was determined using the Wade reagent and sodium phytate as a standard (LATTA; ESKIN, 1980; FRÜHBECK et al., 1995).

\section{Phenolic compounds}

The extraction of phenolic compounds was performed with $50 \%$ methanol in reflux for three consecutive times at $80^{\circ} \mathrm{C}$, in the ratio $1: 25(\mathrm{w} / \mathrm{v})$. The extracts were combined, evaporated to $25 \mathrm{~mL}$ and subjected to the determination, using the Folin-Denis (ASSOCIATION..., 2005). The tannic acid was used as standard.

\section{Technological functional properties}

In order to determine technological functional properties, the Mallory Robot Classic mixer was used at its maximum speed.

Absorption of water and oil

The ASF and ABF were suspended in oil or water, homogenized for 60 seconds with mixer and then centrifuged 
at $2,000 \times \mathrm{g}$ for 10 minutes. The volume of the supernatant was measured and the amount of absorbed water or oil was multiplied by their respective specific gravity to convert into grams (OKEZIE; BELLO, 1988).

\section{Emulsion stability}

The ASF and ABF were dispersed in distilled water and the oil was gradually added at moderate agitation for 30 seconds. Then, the solution was stirred for another 60 seconds to homogenize the system. The homogenate was transferred to a beaker and changing volume of the foam, oil and aqueous phase was determined after 0.5, 2.0 and 6.0 hours (OKEZIE; BELLO, 1988).

\section{Foam volume}

The ASF and ABF were suspended in distilled water and homogenized with mixer for 3.5 minutes. Subsequently, the mixture was transferred to a beaker for determining volumes of foam at different times $(0,30,60$ and 120 minutes after the agitation for 3.5 minutes). The volume of the foam remained over time was calculated considering $100 \%$ the specific foam volume at time zero (WANG; CABALLERO-CORBOBA; SGARBIERI, 1992).

\section{Emulsifying activity}

It was weighed $5 \mathrm{~g}$ of flour and suspended in distilled water $(40 \mathrm{~mL})$ and the $\mathrm{pH}$ was adjusted to 7.0 with $\mathrm{NaOH}$ or $\mathrm{HCl}$. Afterwards, the suspension was stirred for 15 minutes. The $\mathrm{pH}$ of the suspension was checked and adjusted again and the final volume was completed to $50 \mathrm{~mL}$ with distilled water. To this suspension was added $50 \mathrm{~mL}$ of soybean oil, keeping it under stirring for 3 minutes. The new emulsion obtained was centrifuged at 2,000 $\times \mathrm{g}$ for 5 minutes $(\mathrm{DENCH}$; RIVAS; CAYGILL, 1981). After visual reading of the graduated centrifuge tubes, the emulsifying activity was calculated by dividing the height of the layer by the total height of the emulsifying fluid x 100 .

\section{Results and discussion}

Most flour particles were retained on sieves sized 40 mesh $(0.425 \mathrm{~mm})$ to 80 mesh $(0.180 \mathrm{~mm})$. According to Zanotto and Bellaver (1996), the uniformity index indicates the relative proportion between coarse, medium and fine particles, which are defined according to diameters larger than $2 \mathrm{~mm}$, between 2 and $0.60 \mathrm{~mm}$, and lower than $0.60 \mathrm{~mm}$, respectively. Therefore, ASF and ABF particles were classified as fine.
The results of phytochemical screening indicated the presence of different metabolic groups of nutritional and pharmacological interest in both flours, such as tannins, flavonoids, depsides, depsidones, and coumarins. Cardiac glycosides, steroids and alkaloids were not detected in any of the flours.

Both flours showed low contents of crude protein (ASF:

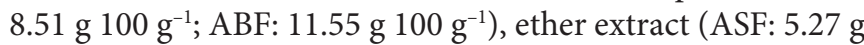

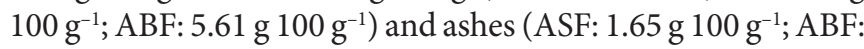

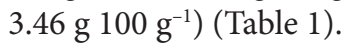

While studying ASF, Aguiar et al. (2010) found $18.70 \mathrm{~g}$ $100 \mathrm{~g}^{-1}$ of proteins in dry matter (DM), a far higher level than registered in this study. Regarding ether extract, Aguiar et al.

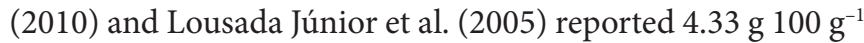

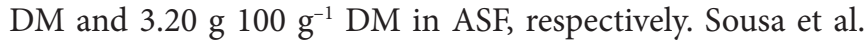
(2011), while analyzing residues of acerola (seeds, small amount

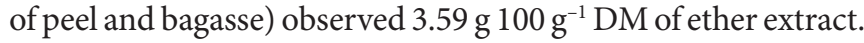

The content of ash detected in ASF and ABF were higher than reported by Aguiar et al. (2010) that recorded $0.49 \mathrm{~g}$ $100 \mathrm{~g}^{-1} \mathrm{DM}$ in ASF, and by Sousa et al. (2011), who found $0.55 \mathrm{~g}$ $100 \mathrm{~g}^{-1} \mathrm{DM}$ in residues of acerola (seeds, small amount of peel and bagasse).

ASF showed a higher content of insoluble fibers (75.66 g $\left.100 \mathrm{~g}^{-1} \mathrm{DM}\right)$, whereas ABF had higher content of soluble fibers

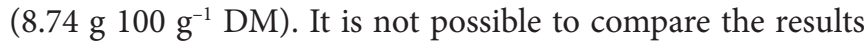
of fibers of the present study with the literature, because the methodology used was not the same. These differences in the proximate composition are probably due to several factors affecting the crops and to fruit variety. In addition, the differences are due to the use of all residues from acerola processing and not only seeds or bagasse.

IOM (INSTITUTE..., 2005) recommends consuming 25 to $38 \mathrm{~g}$ fibers per day. Thus, consuming approximately 17 to $26 \mathrm{~g}$ of ASF and 38 to $57 \mathrm{~g}$ of ABF supplies half the recommended intake. Thus, the presence of high contents of fibers in both ASF and $\mathrm{ABF}$ may contribute to a better use of these residues, since the evolution of scientific knowledge allowed us to conclude that dietary fiber ingestion is related to health maintenance and prevention of some diseases such as constipation, colon disease, diverticular disease, and colon cancer as well as systemic diseases such as hyperlipidemia, cardiovascular disease, diabetes, obesity (INSTITUTE..., 2005). Since several studies have demonstrated fiber effectiveness in the treatment and prevention of some diseases, ASF and ABF may provide beneficial effects to the human body. Nitrogen-free extract consists primarily of sugars. Thus, the highest content was found in ABF.

Table 1. Proximate composition in $\mathrm{g} 100 \mathrm{~g}^{-1}$ of dry matter of acerola seed flour (ASF) and acerola bagasse flour (ABF).

\begin{tabular}{cccccccc}
\hline \multirow{2}{*}{ Sample } & \multirow{2}{*}{ Moisture } & \multirow{2}{*}{ Crude Protein $^{1}$} & \multirow{2}{*}{ Ether Extract ${ }^{1}$} & \multirow{2}{*}{ Ashes $^{1}$} & \multicolumn{2}{c}{ Dietary Fiber $^{1}$} \\
\cline { 5 - 6 } & & & & Soluble & Insoluble $^{*}$ NFE $^{1 \star}$ \\
ASF & $9.20 \pm 0.18$ & $8.51 \pm 0,11$ & $5.27 \pm 0.18$ & $1.65 \pm 0.05$ & $4.76 \pm 0.98$ & $75.66 \pm 1.58$ & $4.15 \pm 1.48$ \\
ABF & $10.90 \pm 0,40$ & $11.55 \pm 0,09$ & $5.61 \pm 0.98$ & $3.46 \pm 0.05$ & $8.74 \pm 0.53$ & $28.58 \pm 1.24$ & $42.06 \pm 2.49$ \\
\hline
\end{tabular}

${ }^{1}$ Data represent the mean of triplicate determinations \pm standard deviation. ${ }^{\star N F E}$ : Nitrogen-free extract. 
Minerals participate in several functions in the human body, such as the regulation of metabolism. Calcium and potassium presented the highest contents (Table 2). Calcium showed higher content in ASF (264.32 mg $\left.100 \mathrm{~g}^{-1} \mathrm{DM}\right)$ whereas potassium content was higher in ABF (791.25 mg $\left.100 \mathrm{~g}^{-1} \mathrm{DM}\right)$. ASF also showed higher levels of copper, manganese, iron and zinc.

Iron is an important mineral for health of the human body, as it helps to form red blood cells. However, despite its abundance in food, iron deficiency anemia is still common today. The recommended daily intake of iron for adults is $18 \mathrm{mg}$ (INSTITUTE..., 2002), therefore, taking about $85 \mathrm{~g}$ of ASF would be sufficient to satisfy this need. But, it is important not to infer that all the iron present in food is absorbed by the body, so it can not refer to the ASF as a food rich in iron, it is necessary to check the availability of this mineral.

Mineral results in ASF differs from those reported by Aguiar et al. (2010), who used plasma mass spectrometry to register calcium: $46.09 \mathrm{mg} 100 \mathrm{~g}^{-1} \mathrm{DM}$, potassium: $45.68 \mathrm{mg}$ $100 \mathrm{~g}^{-1} \mathrm{DM}$, magnesium: $24.55 \mathrm{mg} 100 \mathrm{~g}^{-1} \mathrm{DM}$, phosphorus: $0.09 \mathrm{mg} 100 \mathrm{~g}^{-1} \mathrm{DM}$, copper: $1.66 \mu \mathrm{g} 100 \mathrm{~g}^{-1}$, manganese: $0.82 \mathrm{mg}$ $100 \mathrm{~g}^{-1} \mathrm{DM}$, iron: $41.09 \mathrm{mg} 100 \mathrm{~g}^{-1} \mathrm{DM}$, and zinc: $0.10 \mathrm{mg}$ $100 \mathrm{~g}^{-1} \mathrm{DM}$. These differences are probably due to many factors affecting the crops, to acerola variety (acid variety), and even to the experiment methods.

The vitamin $\mathrm{C}$ content of the ASF and of the ABF were 457.32 and $10,282.45 \mathrm{mg} 100 \mathrm{~g}^{-1} \mathrm{DM}$, respectively. Sousa et al. (2011) while studying the residue of acerola (seed, small amount of bark, and pulp rest) recorded a significantly lower content of vitamin C: $89.55 \mathrm{mg} 100 \mathrm{~g} \mathrm{~g}^{-1} \mathrm{DM}$ and Correia et al. (2012) in acerola residue (seed, small amount of bark, and pulp rest) reported 2,748.03 $\mathrm{mg} 100 \mathrm{~g}^{-1} \mathrm{DM}$, higher than the ASF and lower than the ABF of this work. Aquino et al. (2010), though, verified 10,448.15 mg $100 \mathrm{~g}^{-1} \mathrm{DM}$ of vitamin $\mathrm{C}$ in the acerola residues flour (seed, small amount of bark, and pulp rest), the approximate content of the ABF. The recorded differences are

Table 2. Mineral composition in mg $100 \mathrm{~g}^{-1}$ of dry matter in acerola seed flour (ASF) and acerola bagasse flour (ABF).

\begin{tabular}{ccc}
\hline Minerals $^{1}$ & ASF & ABF \\
\hline Calcium & $264.32 \pm 9$ & $86.98 \pm 5.61$ \\
Potassium & $178.96 \pm 5,51$ & $791.25 \pm 26.72$ \\
Magnesium & $77.09 \pm 0$ & $106.62 \pm 6.48$ \\
Phosphorus & $99.12 \pm 0$ & $151.52 \pm 6.48$ \\
Copper & $0.81 \pm 0.01$ & $0.44 \pm 0$ \\
Manganese & $0.21 \pm 0.01$ & $0.11 \pm 0.03$ \\
Iron & $21.15 \pm 0.59$ & $5.88 \pm 0.98$ \\
Sulfur & $115.64 \pm 6,36$ & $140.29 \pm 9.83$ \\
Zinc & $4.24 \pm 0.16$ & $1.72 \pm 0.07$
\end{tabular}

${ }^{1}$ Data represent the mean of triplicate determinations \pm standard deviation. Moisture content of flours in $\mathrm{g} 100 \mathrm{~g}^{-1}$ : ASF: 9.20 and ABF: 10.90 . probably related to the use of all the residue of the acerola processing, and not only the seeds or the bagasse.

The recommended daily intake of vitamin C is $90 \mathrm{mg}$ for men and $75 \mathrm{mg}$ for women (INSTITUTE..., 2000). Thus, the ingestion of $19.68 \mathrm{~g}$ and $16.40 \mathrm{~g}$ of ASF or $0.88 \mathrm{~g}$ and $0.73 \mathrm{~g}$ of $\mathrm{ABF}$ represents an intake of $90 \mathrm{mg}$ and $75 \mathrm{mg}$ of vitamin $\mathrm{C}$, respectively, which would practically supply the recommended daily need. The ASF and the ABF are, thus, good sources of vitamin $C$ with potential for use, and can be used to enrich foods, cosmetics and contribute to its antioxidant activity.

In addition to the nutrients present in these flours, antinutritional and bioactive compounds can also be found. Although some are health hazards, others provide benefits depending on the concentration, such as polyphenols and saponins.

ABF showed the highest content of nitrate, whereas ASF had the highest levels of saponins (Table 3 ). The acceptable daily intake of nitrate set by the World Health Organization is $5 \mathrm{mg} \mathrm{kg}^{-1}$ body weight. Thus, a $50 \mathrm{~kg}$ person could ingest $250 \mathrm{mg}$ of nitrate, which is only found in amounts above $312 \mathrm{~g}$ ASF and $125 \mathrm{~g}$ ABF. Hence, nitrate contents in these flours pose no health hazards.

The major adverse effects of saponins are changes in reproduction and growth and decrease in nutrient absorption due to changes in cell membrane permeability (FRANCIS et al., 2002). No references to acceptable daily intake of saponins were found in the available literature.

Oxalic acid and trypsin inhibitors were not detected in the flours (Table 3).

ASF showed the highest content of phytate (Table 3). Phytate levels in ASF and ABF are within the range reported for groups of cereals and legumes, which varies from $0.19 \mathrm{~g}$ to $1.37{\mathrm{~g} 100 \mathrm{~g}^{-1}}^{-1}$ (JOUNG et al., 2004).

Phytate can act as anti-nutritional factor, as it chelates minerals and prevents bioavailability (FREDLUND et al., 2006); however, some studies have suggested beneficial effects for health, e. g. protective role in carcinogenesis (NORAZALINA et al., 2010); antioxidant function (FREDLUND et al., 2006) and glycemic control (KIM et al., 2010).

No levels of nitrate, saponins, oxalic acid, trypsin inhibitors or phytate were found in acerola or its fractions in the published literature for comparison.

The content of phenolic compounds was high in both flours (Table 3). The major adverse effects of phenolic compounds are the inhibition of certain digestive enzymes such as trypsin, composition of protein complexes and decrease in protein digestibility (SATHE, 2002). No references as for

Table 3. Bioactive compound contents in $\mathrm{g} 100 \mathrm{~g}^{-1}$ of dry matter in acerola seed flour (ASF) and acerola bagasse flour (ABF).

\begin{tabular}{ccccccc}
\hline Samples & Nitrate $^{1}$ & Saponins $^{1}$ & Oxalic acid $^{1}$ & Tripsin inhibitors $^{1}$ & Phytate $^{1}$ & Phenolic compounds $^{1}$ \\
\hline ASF & $0.08 \pm 0,02$ & $0.49 \pm 0.01$ & ND $^{*}$ & ND $^{*}$ & $0.23 \pm 0,04$ & $4.73 \pm 0.07$ \\
ABF & $0.20 \pm 0.06$ & $0.26 \pm 0.01$ & ND $^{*}$ & ND $^{*}$ & $0.18 \pm 0.04$ & $10.82 \pm 0.09$ \\
\hline
\end{tabular}

${ }^{1}$ The data are mean of triplicate determinations \pm standard deviation. ${ }^{*} \mathrm{ND}$ : Not Detected. Moisture content of flours in $\mathrm{g} 100 \mathrm{~g}{ }^{-1}:$ ASF: 9.20 and $\mathrm{ABF}: 10.90$. 
Table 4. Stability of emulsion: mean volumes of foam, oil and aqueous phase in times: $0.5 ; 2.0$ and 6.0 hours after stirring of acerola seed flour (ASF) and acerola bagasse flour (ABF).

\begin{tabular}{ccccc}
\hline \multirow{2}{*}{ Samples } & Time after & \multicolumn{3}{c}{ Mean volumes (mL) } \\
\cline { 2 - 5 } & stirring (hours) & Foam $^{1}$ & Oil $^{1}$ & Aqueous Phase $^{1}$ \\
\hline \multirow{2}{*}{ ASF } & 0.5 & $1.00 \pm 0.01$ & $17.67 \pm 2.08$ & $37.33 \pm 1.15$ \\
& 2.0 & 0 & $12.67 \pm 2.08$ & $41.33 \pm 0.58$ \\
& 6.0 & 0 & $11.33 \pm 0.58$ & $42.67 \pm 0.58$ \\
\hline \multirow{2}{*}{ ABF } & 0.5 & 0 & $53.07 \pm 2.48$ & $2.33 \pm 2.08$ \\
& 2.0 & 0 & $47.67 \pm 2.89$ & $8.33 \pm 3.06$ \\
\hline
\end{tabular}

${ }^{1}$ Data represent the mean of triplicate determinations \pm standard deviation.

acceptable daily intake of phenolic compounds were found in the published literature. Thus, the use of these flours in feeding must be performed with caution, owing to the high levels of phenolic compounds.

The mean percentages of water and oil absorption were $300 \%$ and $373.33 \%$ in ASF, respectively. Oil absorption in ASF was higher than water absorption, possibly due to the presence of a higher number of hydrophobic groups which can bind to oil. In ABF, water and oil absorption were $591.67 \%$ and $320 \%$, respectively. This high rate of water absorption may be related to the high content of soluble fibers in this flour, as these fibers have high capacity of water retention. Therefore, ABF can be used in meat and bakery products, as it enables more addition of water to the dough thus improving its handling characteristics.

Cheftel, Cuq and Lorient (1985) suggested that water absorption and water retention play an important role in the texture quality of a wide variety of foods, particularly meat products. Similarly, the capacity of oil absorption is also required in meat formulation, meat substitutes and analogues (ABBEY; IBEH, 1988). The technological functional properties of protein-water interaction (water retention) are important in the formulation of certain foods, especially meat products (cold meats, sausages, meatballs, and savory nibbles) in which proteins also play an important role in thickening, providing greater consistency to the product (CHEFTEL; CUQ; LORIENT, 1985). Thus, both flours analyzed in this study showed satisfactory values which make them function in industrialized food products requiring this feature.

ASF and ABF showed no foam formation either during the mixing process or after. According to Cheftel, Cuq and Lorient (1985) an explanation for no foam formation is related to protein content, as foam formation requires flexible-chain proteins, which are poor in secondary and tertiary structures that adapt quickly in the air-liquid phase. Furthermore, these proteins must have the possibility to form hydrophobic bonds on their surface. Therefore, we believe that the proteins had their structures changed in both flours. Stability is important in formulations requiring foam formation, such as meringues, mousses and cakes (OKEZIE; BELLO, 1988; FENNEMA, 2000).

Emulsifying properties are technological functional properties important in food formulations such as meat products, mayonnaise, sauces, soups, cream cheese, and others (CHEFTEL; CUQ; LORIENT, 1989). According to this study, the emulsifying activity of ASF and ABF were $23.3 \%$ and $3.39 \%$, respectively. For emulsion stability, the mean volumes of foam, oil and aqueous phase in ASF and ABF are listed in Table 4.

However, when the stability of each phase was analyzed (foam, oil, and water) considering the time after mixing process, we observed a slight reduction in oil volume and a little increase in water volume over time. Hence, ASF and ABF showed high emulsion stability, as water and oil phases were not completely separated 6 hours after sample mixing.

It is greatly difficult to compare the results obtained in this study with others mentioned in previous researches due to the lack of both methodology standardization and conditions for assessing emulsion properties, since they are affected by several factors such as $\mathrm{pH}$, temperature, type and geometry of the equipment used in the experiment, rate of oil addition, and emulsifying properties of proteins (FENNEMA, 2000).

\section{Conclusions}

ASF and ABF showed high levels of dietary fibers and minerals, as well as high emulsion stability and water and oil absorption capacity. Therefore, the flours have potential to be incorporated into meat and bakery products.

Among antinutritional factors, phenolic compounds stood out with high levels. Since they can bring benefits to the human body and also be related to nutritional deficiencies, these flours should be used with caution.

\section{Acknowledgements}

To the Fundação de Amparo a Pesquisa de Minas Gerais - FAPEMIG, the Coordenação de Aperfeiçoamento de Pessoal de Nível Superior - CAPES, and Conselho Nacional de Desenvolvimento Científico e Tecnológico - CNPq.

\section{References}

ABBEY, B. W.; IBEH, G. O. Functional properties of raw and heat processed couwpea (Viagna unguiculata) flour. Journal of Food Science, v. 53, p. 1775-1791, 1988. http://dx.doi. org/10.1111/j.1365-2621.1988.tb07840.x

AGUIAR, T. M. et al. Caracterização química e avaliação do valor nutritivo de sementes de acerola. Revista da Sociedade Brasileira de Alimentos e Nutrição, v. 35, n. 2, p. 91-102, 2010. 
ASSOCIATION OF OFFICIAL ANLYTICAL CHEMISTS - AOAC. Official methods of analysis of the association of the analytical chemists. 18th ed. Washington: AOAC, 2005.

AQUINO, A. C. M. S. et al. Avaliação físico-química e aceitação sensorial de biscoitos tipo cookies elaborados com farinha de resíduos de acerola. Revista Instituto Adolfo Lutz, v. 69, n. 3, p. 379-386, 2010.

BACCOU, J. C.; LAMBERT, F.; SAUVAIRE, Y. Spectrometric method for the determination of total steroidal sapogenin. Analyst, v. 102, p. 458-465, 1977. http://dx.doi.org/10.1039/an9770200458

CATALDO, D. A. et al. Rapid colorimetric determination of nitrate in plant tissue by nitration of salicylic acid. Communications in Soil Science and Plant Analysis, v. 6, p. 71-80, 1975. http://dx.doi. org/10.1080/00103627509366547

CHEFTEL, J. C.; CUQ, J. L.; LORIENT, D. Proteines alimentaires. Paris: Techinique et documentation, 1985.

CHEFTEL, J. C.; CUQ, J. L.; LORIENT, D. Proteínas alimentarias: bioquímica, propiedades funcionales, valor nutricional, modificaciones químicas. Zagaroza: Editora Acribia, 1989.

CORREIA, R. T. P. et al. Bioactive compounds and phenolic-linked functionality of powdered tropical fruit residues. Food Science and Technology International, v. 18, n. 6, p. 539-547, 2012. PMid:23014856. http://dx.doi.org/10.1177/1082013211433077

DENCH, J. E.; RIVAS, R. N.; CAYGILL, J. C. Selected functional properties of sesame (Sesamuindicum L.) flour and two protein isolates. Journal of the Science of Food and Agriculture, v. 32, p. 557-564, 1981. http://dx.doi.org/10.1002/jsfa.2740320606

ERLANGER, B. F.; KOKOWSKY, N.; COHEN, W. The preparation and properties of two new chromogenic substrates of trypsin. Archives of Biochemistry and Biophysics, v. 95, p. 271-278, 1961. http:// dx.doi.org/10.1016/0003-9861(61)90145-X

FENNEMA, O. R. Química de los alimentos. 2. ed. Zaragoza: Acribia., 2000.

FRANCIS, G. et al. The biological action of saponins in animal systems: a review. British Journal of Nutrition, v. 88, n. 6, p. 587-605, 2002. PMid:12493081. http://dx.doi.org/10.1079/BJN2002725

FREDLUND, K. et al. Absorption of zinc and retention of calcium: dose-dependent inhibition by phytate. Journal of Trace Elements in Medicine and Biology, v. 20, n. 1, p. 49-57, 2006. PMid:16632176. http://dx.doi.org/10.1016/j.jtemb.2006.01.003

FRÜHBECK, G. et al. A modified method for the indirect quantitative análisis of phytate in foodstuffs. Analytical Biochemistry, v. 225, n. 2, p. 206-212, 1995. PMid:7762782. http://dx.doi.org/10.1006/ abio. 1995.1145

INSTITUTE OF MEDICINE OF THE NATURAL ACADEMIES - IOM. Dietary Reference Intakes for Energy, Carbohydrate, Fiber, Fat, Fatty Acids, Cholesterol, Protein and Amino Acids. Washington: National Academy Press, 2005.

INSTITUTE OF MEDICINE OF THE NATURAL ACADEMIES - IOM. Dietary reference intakes for vitamin $A$, vitamin $K$, arsenic, boron, chromium, copper, iodine, iron, manganese, molybdenum, nickel, silicon, vanadium, and zinc. Washington: National Academy Press, 2002.

INSTITUTE OF MEDICINE OF THE NATURAL ACADEMIES - IOM. Dietary reference intakes for Vitamin C, Vitamin E, Selenium and Carotenoids. Washington: National Academy Press, 2000.

JOUNG, H. et al. Bioavailable zinc intake of Korean adults in relation to the phytate content of Korean foods. Journal of Food Composition and Analysis, v. 17, p. 713-724, 2004. http://dx.doi.org/10.1016/j. jfca.2003.10.002
KAKADE, M. L. et al. Determination of trypsin inhibitor activity of soy product: A collaborative analysis of an improved procedure. Cereal Chemistry, v. 51, p. 376-382, 1974.

KIM, S. M. et al. Modulatory effect of rice bran and phytic acid on glucose metabolism in high fat-fed C57BL/6N mice. Journal of Clinical Biochemistry and Nutrition, v. 47, n. 1, p. 12-17, 2010. PMid:20664725 PMCid:PMC2901758. http://dx.doi.org/10.3164/ jcbn.09-124

LATTA, M.; ESKIN, M. A simple and rapid colorimetric method for phytate determination. Journal Agricultural Food Chemistry, v. 28 , p. 1313-1315, 1980. http://dx.doi.org/10.1021/jf60232a049

LOURES, A.; JOKL, L. Microtécnica para determinação de ácido oxálico em folhas e derivados. In: ENCONTRO NACIONAL DE ANALISTAS DE ALIMENTOS, 6.,1990, Curitiba. Resumos... Curitiba: Instituto de Tecnologia do Paraná, 1990. p. 59.

LOUSADA JÚNIOR, J. E. et al. Consumo e digestibilidade de subprodutos do processamento de frutas em ovinos. Revista Brasileira de Zootecnia, v. 34, n. 2, p. 659-669, 2005. http://dx.doi. org/10.1590/S1516-35982005000200036

LOUSADA JÚNIOR, J. E. et al. Caracterização físico-química de subprodutos obtidos do processamento de frutas tropicais visando seu aproveitamento na alimentação animal. Revista Ciência Agronômica, v. 37, n. 1, p. 70-76, 2006.

MALAVOLTA, E.; VITTI, G. C.; OLIVEIRA, A. S. Avaliação do estado nutricional das plantas: princípios e aplicações. 2. ed. Piracicaba: POTAFOS, 1997.

MATOS, F. J. A. Introdução à fitoquímica experimental. 2. ed. Fortaleza: Edições UFC, 1997.

NAVES, L. P. et al. Nutrientes e propriedades funcionais em sementes de abóbora (Cucúrbita maxima) submetida a diferentes processamentos. Revista Ciência e Tecnologia de Alimentos, v. 30, p. 195-190, 2010. Suplemento 1.

NORAZALINA, S. et al. Anticarcinogenic efficacy of phytic acid extracted from rice bran on azoxymethane-induced colon carcinogenesis in rats. Experimental and Toxicologic Pathology, v. 62 , n. 3, p. 259-268, 2010. PMid:19464858. http://dx.doi. org/10.1016/j.etp.2009.04.002

NUNES, p. M. P. et al. A importância do aproveitamento dos resíduos industriais da semente de citrus. Visão Acadêmica, v. 10, n. 1, 2009.

OKEZIE, B. O.; BELLO, A. B. Physicochemical and functional properties of winged bean flour and isolate compared with soy isolate. Journal of Food Science, v. 53, p. 450-454, 1988. http:// dx.doi.org/10.1111/j.1365-2621.1988.tb07728.x

SATHE, S. K. Dry bean protein functionality. Critical Reviews in Biotechnology, v. 22, n. 2, p. 175-223, 2002. PMid:12135167. http:// dx.doi.org/10.1080/07388550290789487

SOUSA, M. S. B. et al. Caracterização nutricional e compostos antioxidantes em resíduos de polpas de frutas tropicais. Revista Ciência Agrotécnica, v. 35, n. 3, p. 554-559, 2011.

STROHECKER, R.; HENNING, H. M. Analisis de vitaminas: metodos comprobados. Madrid: Paz Montalvo, 1967. 428 p.

WANG, S. H.; CABALLERO-CORBOBA, G. M.; SGARBIERI, V. C. Propriedades funcionais de misturas de farinhas de trigo e sojadesengordurada, pré-tratada por microondas. Ciência e Tecnologia de Alimentos, v. 12, n. 1, p. 14-25, 1992.

ZANOTTO, D. L.; BELLAVER, C. Método de determinação da granulometria de ingredientes para uso em rações de suínos e aves. Embrapa/CNPSA, 1996. p. 1-5. (Comunicado Técnico). 